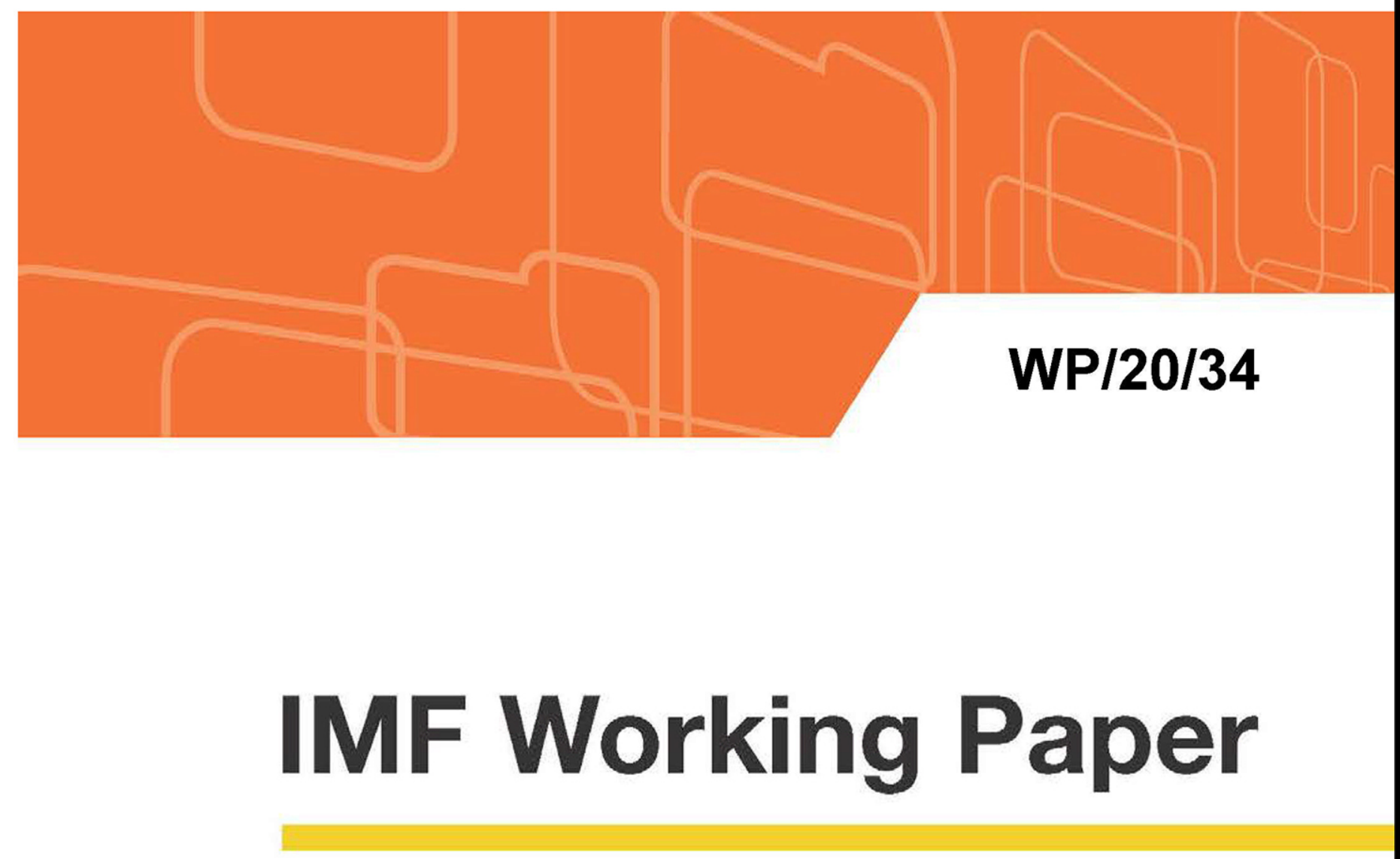

\title{
Barbados' 2018-19 Sovereign Debt Restructuring-A Sea Change?
}

by Myrvin Anthony, Gregorio Impavido, and Bert van Selm

IMF Working Papers describe research in progress by the author(s) and are published to elicit comments and to encourage debate. The views expressed in IMF Working Papers are those of the author(s) and do not necessarily represent the views of the IMF, its Executive Board, or IMF management. 


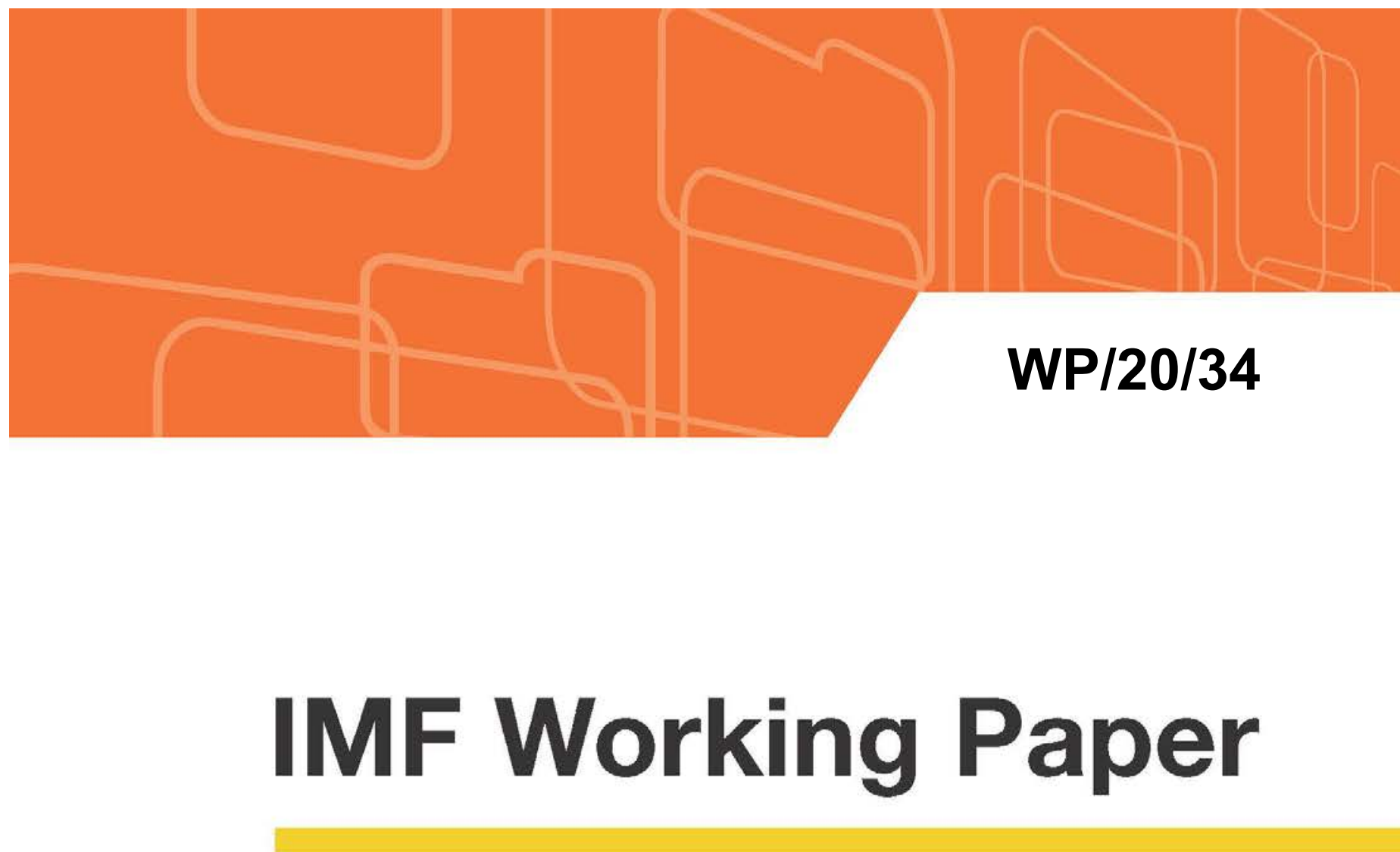

\section{Barbados' 2018-19 Sovereign Debt Restructuring-A Sea Change?}

by Myrvin Anthony, Gregorio Impavido, and Bert van Selm

IMF Working Papers describe research in progress by the author(s) and are published to elicit comments and to encourage debate. The views expressed in IMF Working Papers are those of the author(s) and do not necessarily represent the views of the IMF, its Executive Board, or IMF management.

I N T E R N A T I O N A L M O N E T A R Y F U N D 


\title{
IMF Working Paper
}

\author{
Western Hemisphere Department
}

\section{Barbados' 2018-19 Sovereign Debt Restructuring-A Sea Change? Prepared by Myrvin Anthony, Gregorio Impavido, and Bert van Selm*}

\author{
Authorized for distribution Thordur Jonasson and Aasim M. Husain
}

February 2020

\section{This Working Paper should not be reported as representing the views of the IMF.} The views expressed in this Working Paper are those of the author(s) and do not necessarily represent those of the IMF or IMF policy. Working Papers describe research in progress by the author(s) and are published to elicit comments and to further debate.

\begin{abstract}
This paper examines the causes, processes, and outcomes of Barbados' 2018-19 sovereign debt restructuring - its first ever. The restructuring was comprehensive, featuring several rarely used approaches, including the restructuring of treasury bills, and the use of a retrofitted collective action mechanism. The debt restructuring has helped to set Barbados' public debt on a clear downward trajectory. A sustained reform effort, maintaining high primary surpluses and ambitious structural reforms, will be needed to gradually reduce public debt from about 160 percent of GDP before the restructuring to the country's 60 percent debt-to-GDP target.
\end{abstract}

JEL Classification Numbers: F34; G15; H63

Keywords: Sovereign Debt; Sovereign Defaults; Sovereign Debt Restructuring; Barbados Authors’ Email Addresses: manthony@imf.org; gimpavido@imf.org; bvanselm@imf.org

\footnotetext{
*Myrvin Anthony and Gregorio Impavido are senior economists in the Monetary and Capital Markets and the Western Hemisphere Departments. Bert van Selm is a deputy division chief in the Western Hemisphere Department. We would like to thank Julianne Ams, Judith Gold, Tamon Asonuma, and participants in a seminar held at the IMF on January 23, 2020 for their contributions and comments on an earlier draft. MCM colleagues James Knight and Laszlo Butt provided critical inputs at different stages of the process. The usual disclaimer applies.
} 
III. RESTRUCTURING THE DEBT: PERIMETER AND PROCESS ________



B. Retrofitted Collective Action Mechanism____

C. Bilateral Debt_____ $-\frac{10}{10}$

D. External Debt Restructuring____ $-\frac{10}{11}$

E. Natural Disaster Clause_________

IV. BARBADOS' IMF-SUPPORTED ECONOMIC REFORM PROGRAM ___

A. The BERT plan____

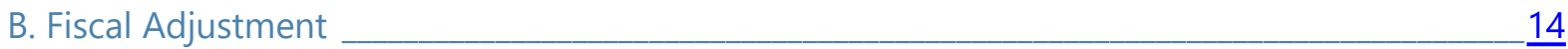

C. Structural Reforms ________- $-\frac{14}{15}$

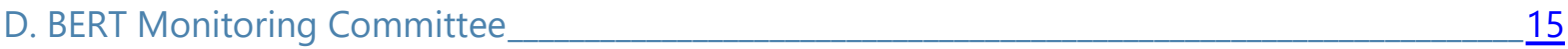

V. RESTRUCTURING THE DEBT: OUTCOMES ___

A. Stress tests

B. Government Debt Held by Domestic Banks ___

C. Statutory reserve requirements _______



E. Government Debt Held by the Central Bank of Barbados______ 20

F. Government Debt Held by the National Insurance Scheme (NIS) ____ $\underline{20}$

VI. BARBADOS' DEBT RESTRUCTURING IN A REGIONAL AND GLOBAL PERSPECTIVE___ 22

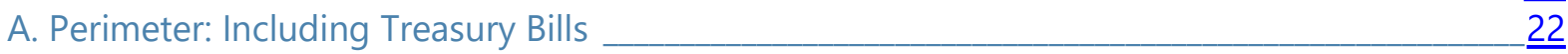

B. Post-Default vs Pre-Default ________

C. Duration of the Debt Restructuring Operation _________

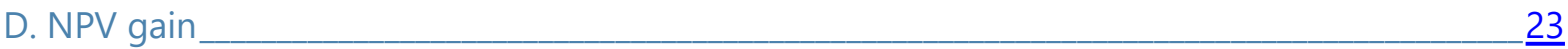

E. Natural Disaster Mechanism_____

F. The Retrofitted Collective Action Mechanism________ 24

G. The Role of the IMF________

VII. LESSONS LEARNED AND CONCLUSION_______

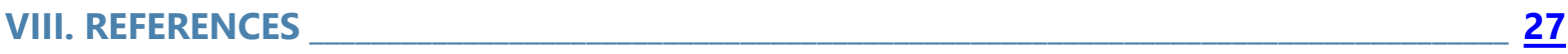

\section{FIGURES}

Figure 1. Public debt and fiscal balance before the program _____ $\underline{6}$

Figure 2. Gross financing needs before the program ______ $\underline{6}$

Figure 3. Gross international reserves before the program _______ $\underline{6}$

Figure 4. External debt service before the program________ $\underline{6}$

Figure 5. Current account financing before the program ________

Figure 6. Capital and financial account before the program ________

Figure 7. Public debt and restructuring perimeter _______ $\underline{7}$ 
Figure 8. External bond spreads before and after the restructuring ___ $\frac{10}{14}$

Figure 9. Fiscal adjustment under the program ___ $\frac{14}{16}$

Figure 10. Public debt projections under the program_____ $\frac{16}{16}$

Figure 11. Gross financing needs projections under the program ___

Figure 12. Public debt maturity projections under the program __ $\frac{16}{16}$

Figure 13. External debt service under the program ___ $\frac{16}{18}$

Figure 14. Interest rates_____ $\frac{18}{19}$

Figure 15. Commercial banks reserves at the CBB ___ $\frac{19}{20}$

Figure 16. Central Bank claims on the Central Government_____ $\frac{20}{21}$

Figure 17. Impact of domestic debt restructuring on NIS ___ 21

TABLES

1. Public debt structure $2007 / 08-17 / 18$

2. Aggregate NPV losses from the domestic debt restructuring 


\section{INTRODUCTION}

In 2018 and 2019, Barbados restructured its public debt for the first time in the country's history. The debt restructuring announced on June 1, 2018, by a government that had assumed office just a week earlier, was very comprehensive, including external debt to commercial creditors and treasury bills. It took many by surprise - prices on the external bond market fell sharply, and it is one of just a handful of cases over the last few decades where treasury bills were included in a debt restructuring (Russia 1998, Ukraine 1998, and Uruguay 2003). Agreement with domestic creditors was announced by the Prime Minister in a public address on October 14, 2018; the process of reaching agreement with external creditors took somewhat longer, with an agreement with the external creditor committee announced just over a year later, on October 18, 2019. To secure full participation in the domestic restructuring, the authorities retrofitted domestic securities with a collective action mechanism, a rarely used approach (with Greece 2012 as a precedent). Most of the newly issued debt instruments include a natural disaster clause, to help Barbados to stay current on future debt obligations.

This paper adds to the empirical literature on sovereign debt restructuring episodes by examining the causes, processes, and outcomes of Barbados' sovereign debt restructuring. It compares these to other recent debt restructurings, in the Caribbean region and beyond. It describes the role of the IMF in the process, with a Fund-supported program approved by the IMF's Executive Board four months into the process, on October 1, 2018; and it discusses the impact on public debt sustainability, and the net present value (NPV) reduction. Compared to other recent debt restructurings in the region: (i) the perimeter of the debt restructuring was relatively wide, to include treasury bills; (ii) the length of the process was somewhat longer than the recent average for the region, at 18 months; and (iii) the NPV gains were substantial. The paper discusses which country-specific factors, and choices made along the way by the Barbadian authorities, contributed to these outcomes.

\section{From Investment Grade to Selective Default}

The 2008-09 global financial crisis led to a prolonged recession in Barbados, with a decade of low growth, and fiscal and external imbalances gradually deepened. Between FY2007/08 and FY2017/18, the overall fiscal balance was on average in deficit at about 8 percent of GDP, with very high interest expenditure and transfers to state-owned enterprises (SOEs), averaging $6 \frac{1}{2}$ and $71 / 2$ percent of GDP, respectively. During this period, public debt (central government debt, arrears, and SOE debt guaranteed by the central government) increased from 77 to 158 percent of GDP. In addition, Barbados' public debt profile worsened considerably. With sovereign credit risk increasing rapidly, commercial banks reduced holdings of long-term debt in favor of short-term debt and, as a result, gross financing needs increased from 16 to 51 percent of GDP. The IMF assessed public debt as unsustainable in its 2017 Article IV report (IMF 2018a: p. 1 and 4). 



\section{A. Credit Rating Downgrades}

With increasing public debt, international investors' confidence gradually deteriorated. Over the last decade, Barbados' credit rating declined in several steps from investment grade (Standard and Poor's BBB + ) on the eve of the global financial crisis, to Selective Default on June 6, 2018. Access to international financing gradually dried up, with no access to international capital market after the 2013/14 Credit Suisse facility (discussed in greater detail below). Between 2007 and 2017, international reserves decreased from US\$850 million to about US $\$ 220$ million. This represented a decrease from $4 \frac{1}{2}$ months to about 5 weeks of import coverage, or from about 140 to 39 percent of the IMF's reserve adequacy (ARA) metric.


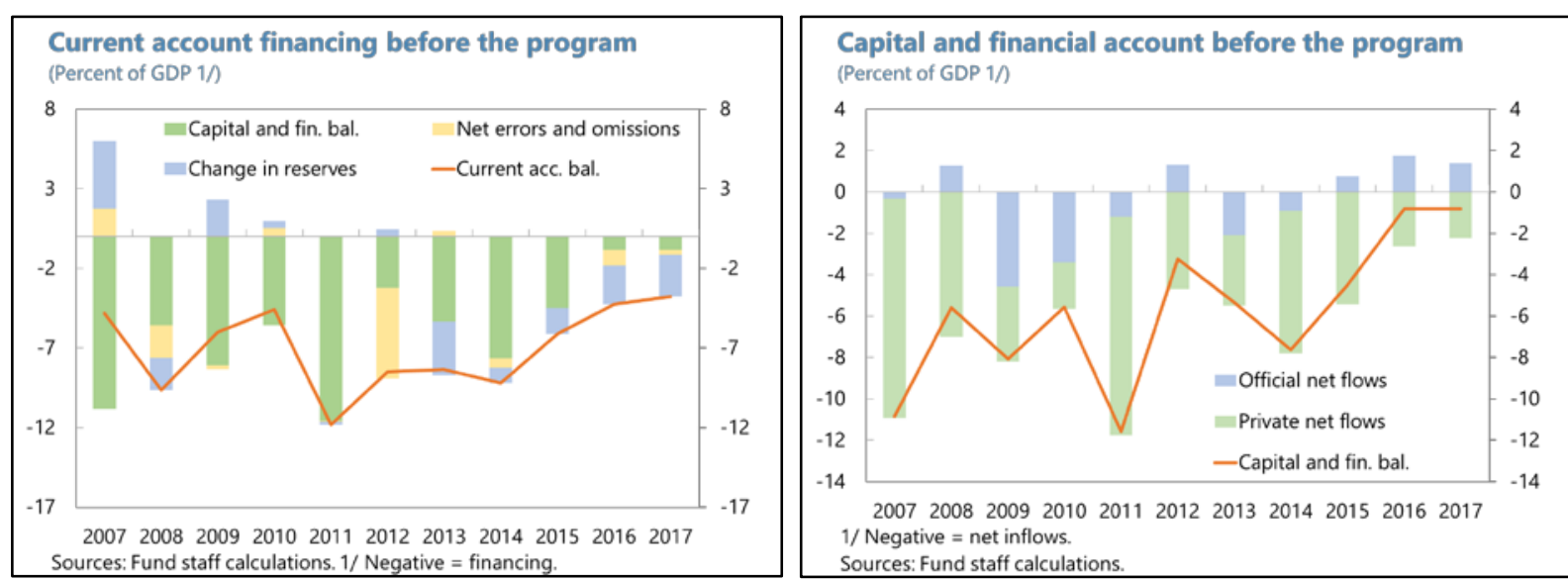

\section{Restructuring the Debt: Perimeter and Process}

Data limitations led to a focus on central government debt. The Barbadian authorities do not consolidate fiscal statistics for larger fiscal perimeters such as general, non-financial and financial public sector. Hence, the definition of public debt used by the authorities included all debt issued by the central government, all arrears incurred by the central government, and all debt issued by SOEs and guaranteed by the central government. This amounted to 158.3 percent of FY GDP at the time of the start of the restructuring (Table 1).

The government announced a comprehensive debt restructuring, including external debt to commercial creditors and treasury bills, on June 1, 2018. Debt targeted for restructuring amounted to about 147 percent of FY GDP, including claims held by public sector agencies such as the Central Bank of Barbados (CBB) and the National Insurance Scheme (NIS). ${ }^{1}$ It covered central government domestic debt including treasury bills and all

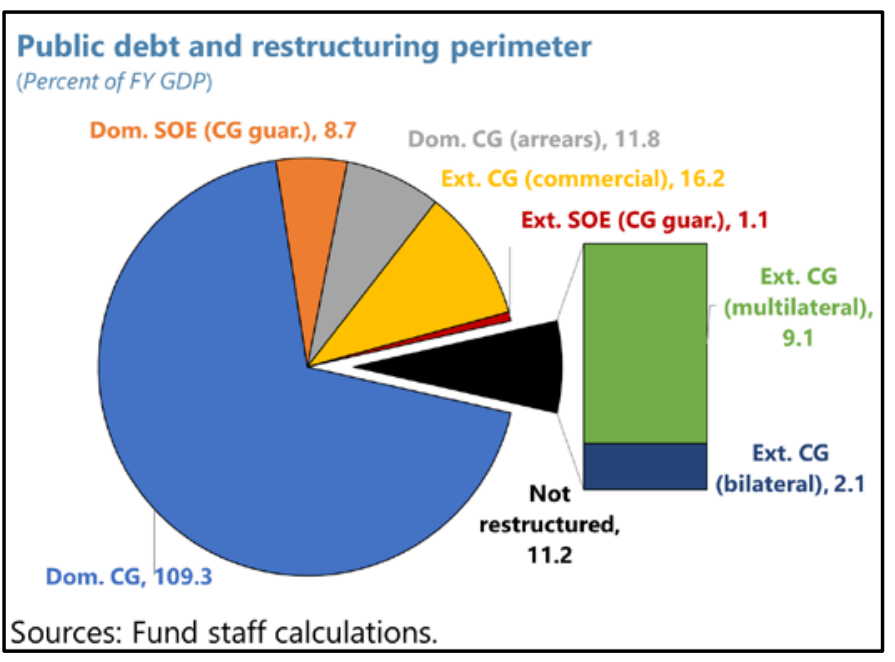

other short-term claims such as overdrafts, central government debt to external commercial creditors, SOE external and domestic debt guaranteed by the central government, domestic expenditure arrears incurred by the central government, and external arrears that started accumulating after the external default. Only bilateral external debt and debt held by multilaterals was excluded from the restructuring perimeter (see text chart).

\footnotetext{
${ }^{1}$ Excluding these claims between public entities, Barbados' public debt at the start of the restructuring would have been about 60 percent of GDP lower.
} 
Table 1. Barbados: Public debt structure, FY2007/08-19/20 (percent of FY GDP)

\begin{tabular}{|c|c|c|c|c|c|c|c|c|c|c|c|c|}
\hline & & & & & & & & & & & & Proj. \\
\hline & $2008 / 09$ & $2009 / 10$ & 2010/11 & $2011 / 12$ & $2012 / 13$ & 2013/14 & 2014/15 & 2015/16 & 2016/17 & 2017/18 & 2018/19 & $2019 / 20$ \\
\hline & \multicolumn{12}{|c|}{ (In millions of Barbados dollars) } \\
\hline Public Debt & 7,847 & 8,965 & 9,868 & 10,466 & 11,444 & 12,657 & 13,092 & 13,949 & 14,548 & 15,843 & 12,853 & 12,152 \\
\hline External & 2,162 & 2,488 & 2,839 & 2,898 & 2,765 & 3,077 & 3,204 & 3,222 & 3,044 & 2,853 & 3,340 & 3,011 \\
\hline Short Term & 0 & 0 & 0 & 0 & 0 & 0 & 0 & 0 & 0 & 0 & 168 & 0 \\
\hline Long term & 2,162 & 2,488 & 2,839 & 2,898 & 2,765 & 3,077 & 3,204 & 3,222 & 3,044 & 2,853 & 3,172 & 3,011 \\
\hline Domestic & 5,685 & 6,476 & 7,029 & 7,568 & 8,679 & 9,579 & 9,888 & 10,727 & 11,504 & 12,990 & 9,513 & 9,141 \\
\hline Short Term & 944 & 1,178 & 1,332 & 1,506 & 2,033 & 2,653 & 2,811 & 3,128 & 3,737 & 5,423 & 892 & 653 \\
\hline Long term & 4,741 & 5,299 & 5,696 & 6,062 & 6,646 & 6,926 & 7,077 & 7,599 & 7,766 & 7,567 & 8,621 & 8,488 \\
\hline Arrears 4/ & 0 & 0 & $\mathbf{0}$ & 0 & 0 & 0 & 0 & 0 & 0 & 1,184 & 461 & 126 \\
\hline External 5/ & 0 & 0 & 0 & 0 & 0 & 0 & 0 & 0 & 0 & 0 & 168 & 0 \\
\hline Domestic & 0 & 0 & 0 & 0 & 0 & 0 & 0 & 0 & 0 & 1,184 & 293 & 126 \\
\hline SOE Guaranteed Debt & 1,158 & 1,211 & 1,328 & 1,401 & 1,411 & 1,400 & 1,543 & 1,342 & 1,242 & 977 & 93 & 93 \\
\hline External 3/ & 204 & 228 & 315 & 357 & 335 & 290 & 399 & 314 & 259 & 108 & 93 & 93 \\
\hline Domestic & 954 & 983 & 1,013 & 1,044 & 1,077 & 1,110 & 1,144 & 1,028 & 983 & 869 & 0 & 0 \\
\hline Short Term & 0 & 0 & 0 & 0 & 0 & 0 & 0 & 0 & 0 & 14 & 0 & 0 \\
\hline Long term & 954 & 983 & 1,013 & 1,044 & 1,077 & 1,110 & 1,144 & 1,028 & 983 & 855 & 0 & 0 \\
\hline CG Debt & 6,689 & 7,754 & 8,540 & 9,065 & 10,033 & 11,257 & 11,549 & 12,607 & 13,306 & 13,683 & 12,299 & 11,934 \\
\hline External 3/6/ & 1,958 & 2,260 & 2,525 & 2,541 & 2,430 & 2,787 & 2,805 & 2,908 & 2,785 & 2,745 & 3,080 & 2,918 \\
\hline Domestic & 4,731 & 5,493 & 6,015 & 6,523 & 7,603 & 8,470 & 8,744 & 9,699 & 10,521 & 10,938 & 9,219 & 9,016 \\
\hline Short Term & 944 & 1,178 & 1,332 & 1,506 & 2,033 & 2,653 & 2,811 & 3,128 & 3,737 & 4,225 & 598 & 528 \\
\hline \multirow[t]{2}{*}{ Long term } & 3,787 & 4,316 & 4,683 & 5,018 & 5,570 & 5,817 & 5,933 & 6,571 & 6,784 & 6,712 & 8,621 & 8,488 \\
\hline & \multicolumn{12}{|c|}{ (In percent of FY GDP) } \\
\hline Public Debt & 83.4 & 100.0 & 108.2 & 112.6 & 123.7 & 135.2 & 139.3 & 147.0 & 149.5 & 158.3 & 125.6 & 115.9 \\
\hline External & 23.0 & 27.8 & 31.1 & 31.2 & 29.9 & 32.9 & 34.1 & 34.0 & 31.3 & 28.5 & 32.6 & 28.7 \\
\hline Short Term & 0.0 & 0.0 & 0.0 & 0.0 & 0.0 & 0.0 & 0.0 & 0.0 & 0.0 & 0.0 & 1.6 & 0.0 \\
\hline Long term & 23.0 & 27.8 & 31.1 & 31.2 & 29.9 & 32.9 & 34.1 & 34.0 & 31.3 & 28.5 & 31.0 & 28.7 \\
\hline Domestic & 60.4 & 72.3 & 77.0 & 81.4 & 93.8 & 102.3 & 105.2 & 113.1 & 118.2 & 129.8 & 93.0 & 87.2 \\
\hline Short Term & 10.0 & 13.1 & 14.6 & 16.2 & 22.0 & 28.3 & 29.9 & 33.0 & 38.4 & 54.2 & 8.7 & 6.2 \\
\hline Long term & 50.4 & 59.1 & 62.4 & 65.2 & 71.8 & 74.0 & 75.3 & 80.1 & 79.8 & 75.6 & 84.2 & 81.0 \\
\hline Arrears 4/ & 0.0 & 0.0 & 0.0 & 0.0 & 0.0 & 0.0 & 0.0 & 0.0 & 0.0 & 11.8 & 4.5 & 1.2 \\
\hline External 5/ & 0.0 & 0.0 & 0.0 & 0.0 & 0.0 & 0.0 & 0.0 & 0.0 & 0.0 & 0.0 & 1.6 & 0.0 \\
\hline Domestic & 0.0 & 0.0 & 0.0 & 0.0 & 0.0 & 0.0 & 0.0 & 0.0 & 0.0 & 11.8 & 2.9 & 1.2 \\
\hline SOE Guaranteed Debt & 12.3 & 13.5 & 14.6 & 15.1 & 15.2 & 14.9 & 16.4 & 14.1 & 12.8 & 9.8 & 0.9 & 0.9 \\
\hline External 3/ & 2.2 & 2.5 & 3.5 & 3.8 & 3.6 & 3.1 & 4.2 & 3.3 & 2.7 & 1.1 & 0.9 & 0.9 \\
\hline Domestic & 10.1 & 11.0 & 11.1 & 11.2 & 11.6 & 11.8 & 12.2 & 10.8 & 10.1 & 8.7 & 0.0 & 0.0 \\
\hline Short Term & 0.0 & 0.0 & 0.0 & 0.0 & 0.0 & 0.0 & 0.0 & 0.0 & 0.0 & 0.1 & 0.0 & 0.0 \\
\hline Long term & 10.1 & 11.0 & 11.1 & 11.2 & 11.6 & 11.8 & 12.2 & 10.8 & 10.1 & 8.5 & 0.0 & 0.0 \\
\hline CG Debt & 71.1 & 86.5 & 93.6 & 97.6 & 108.4 & 120.2 & 122.8 & 132.9 & 136.7 & 136.7 & 120.2 & 113.9 \\
\hline External 3/ 6/ & 20.8 & 25.2 & 27.7 & 27.3 & 26.3 & 29.8 & 29.8 & 30.6 & 28.6 & 27.4 & 30.1 & 27.8 \\
\hline Domestic & 50.3 & 61.3 & 65.9 & 70.2 & 82.2 & 90.4 & 93.0 & 102.2 & 108.1 & 109.3 & 90.1 & 86.0 \\
\hline Short Term & 10.0 & 13.1 & 14.6 & 16.2 & 22.0 & 28.3 & 29.9 & 33.0 & 38.4 & 42.2 & 5.8 & 5.0 \\
\hline Long term & 40.2 & 48.1 & 51.3 & 54.0 & 60.2 & 62.1 & 63.1 & 69.3 & 69.7 & 67.1 & 84.2 & 81.0 \\
\hline \multicolumn{13}{|l|}{ Memorandum items: } \\
\hline Nominal GDP, FY (BDS\$ millio & 9,410 & 8,963 & 9,124 & 9,292 & 9,254 & 9,364 & 9,402 & 9,488 & 9,734 & 10,011 & 10,234 & 10,481 \\
\hline \multicolumn{13}{|c|}{ Sources: Ministry of Finance; Central Bank of Barbados; and Fund staff estimates and projections. } \\
\hline \multicolumn{13}{|c|}{ 1/ Fiscal year (April-March). Ratios expressed relative to fiscal-year GDP. } \\
\hline \multicolumn{13}{|c|}{ 2/ Central Government debt, Central Government arrears, and SOE debt guaranteed by the Central Government. } \\
\hline \multicolumn{13}{|c|}{ 3/ All medium- and long-term. } \\
\hline \multicolumn{13}{|l|}{ 4/ All short-term. } \\
\hline \multicolumn{13}{|c|}{ 5/ Excluding principal amortization arrears. } \\
\hline 6/ Including principal amortiza & arrear & & & & & & & & & & & \\
\hline
\end{tabular}

The timing of the government's announcement was driven by large external debt payments due in early June, and Barbados defaulted on these partly with the aim of maintaining reserves. The incoming government quickly secured the support of experienced advisors to support the sovereign debt restructuring. ${ }^{2}$ In the weeks following the authorities' June 1 announcement,

\footnotetext{
${ }^{2}$ White Oak Advisory provided financial advice to the Government of Barbados, while Cleary Gottlieb LLP provided legal advice. The domestic creditors were advised by FTI Consulting, while external creditors were advised by Newstate Partners LLP.
} 
two main creditor committees were formed: one comprising the five domestic banks, and another group representing the main external creditors.

\section{A. Domestic Debt Restructuring}

Initial discussions took place during June, July and August, both with the domestic and the external creditor committee. Over the summer, the focus of the debt restructuring was on the domestic side, given that the bulk of Barbados' debt was domestic, and given the urgency of reaching a solution with domestic creditors that would provide meaningful debt relief to the government, without jeopardizing financial stability.

Debt service on external debt held by commercial creditors was halted immediately following the June 1 announcement, whereas the government continued to pay interest on domestic debt, with holders of domestic debt expected to roll over maturing principal. Interest on domestic debt continued to be paid until the government launched an exchange offer for domestic debt (Barbados dollar-denominated) on September 7, 2018. The launching of this domestic debt exchange offer was a prior action for the approval of an Extended Arrangement under the Extended Fund Facility (EFF) for Barbados, approved by the IMF's Executive Board on October 1, 2018. The prior action was deemed necessary as the Fund cannot lend into an unsustainable debt situation. The launch of the domestic restructuring was considered necessary in this case to show that a credible process for restructuring was underway that would result in sufficient creditor participation to restore debt sustainability and close financing gaps within the macroeconomic parameters of the program.

\section{B. Retrofitted Collective Action Mechanism}

In September 2018, the parliament of Barbados adopted legislation that retrofitted a collective action mechanism into domestic debt. Under this legislation, in the event of a debt restructuring, creditors holding 75 percent of the aggregate outstanding principal amount of "specified debt instruments" that submit a voting form can, if they accept a restructuring proposal, make the restructuring legally binding for all holders. ${ }^{3,4}$ Agreement with the bulk of domestic creditors (including all banks and insurers) was announced on October 14, and the transaction with domestic creditors was closed on November 19, 2018; the legislation adopted

\footnotetext{
3 "Specified debt instruments" included treasury bills, treasury notes, debentures, local currency loans incurred by the government and by state owned enterprises, local currency bonds issued by the government and state owned enterprises, and local currency arrears incurred or assumed by the government.

${ }^{4}$ According to paragraph 5(1) of the "Debt holder (approval of debt restructuring) Act 2018-24 published in the Supplement to the Official Gazette dated $29^{\text {th }}$ October 2018, the government debt restructuring proposal is deemed accepted by all holders of specified instruments if holders representing at least 50 percent of the aggregate outstanding principal amount of all specified debt instruments submit a voting form, and holders representing at least 75 percent of the aggregate outstanding principal amount for which a voting form is received, vote in favor of the proposal.
} 
by parliament in September was used to secure 100 percent participation in the domestic debt exchange - the retrofitted collective action mechanism was effective.

\section{Bilateral Debt}

On the eve of the debt restructuring, Barbados' debt to bilateral creditors was small, at 2 percent of GDP. After the government's June 1, 2018 announcement, Barbados defaulted on a commercial loan guaranteed by the government of Canada (worth just over 1 percent of GDP), while remaining current on a loan provided by the government of China of just under 1 percent of GDP (IMF 2018b: p. 7). The guarantee was called on September 21, 2108 (IMF 2018b: p. 78), which meant that Barbados was in arrears to Canada from then on. At the IMF Executive Board meeting on October 1, 2018, Canada consented to IMF financing on the condition that: (i) Barbados repaid accumulated arrears to Canada, and (ii) if the loan guaranteed by the government of Canada were restructured, Barbados would seek to restructure other bilateral debt and debt with creditor sovereign guarantees on comparable terms. In early 2019, the government of Barbados decided not to pursue a restructuring of bilateral debt and resumed payments on the Canada loan (IMF 2019a: p. 12).

\section{External Debt Restructuring}

The yield on Barbados' traded external debt jumped sharply following the debt restructuring announcement. External creditors were clearly taken by surprise.

On the eve of the restructuring, external debt to private creditors amounted to about 16 percent of GDP. It consisted of a handful of Eurobond issuances, plus a Credit Suisse loan facility (a facility arranged by Credit Suisse, with participation of other investors). The

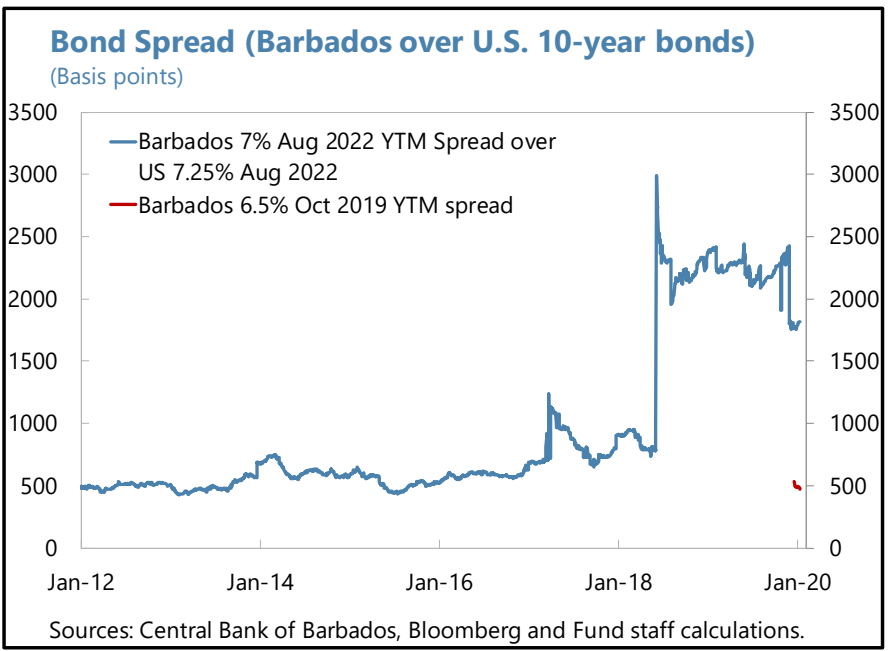
Eurobonds had been issued with collective action clauses (CACs) at 75 percent participation, but the Credit Suisse facility did not have a mechanism to deal with holdout creditors. The Credit Suisse facility was agreed by the government of Barbados in late 2013, for US\$150 million, or about 3 percent of GDP, with a five-year maturity; it was increased to US\$225 million in 2014. The maturity of this loan was originally 5 years, but in 2016 it was extended by one year, to 2019. The interest payable on it was linked to Barbados' credit rating, and it had therefore increased significantly over the years, with numerous downgrades, to 12 percent at end-2017. Barbados' Eurobonds had been issued earlier (the most recent one in 2010), at rates between $6 \frac{1}{2}$ and 8 percent. Several external investors held positions both in the Eurobonds and in the Credit Suisse arrangement. 
During 2019, proposals exchanged between the government of Barbados and the creditor committee gradually narrowed the gap between the positions. The gap between the creditor's initial, September 2018 proposal - a ten year instrument with a single bullet repayment, at 8.25 percent, the average level of the outstanding external debt instruments, with no haircutand the government's initial proposal, which featured very low (but gradually stepping up) interest rates and much longer maturity (at 25 years), was very large in NPV terms. The loss for investors would have been 29 percent under the creditors' proposal, and 59 percent under the government's proposal. ${ }^{5}$ In a series of proposals and counterproposals, this 30-percentage points gap had been reduced to just 5 percent by June 2019. On June 24, 2019, the IMF's Executive Board concluded the first review of Barbados' EFF-supported program.

On October 18, 2019, the government of Barbados and the external creditor committee issued a joint press release to announce agreement on the terms of a debt exchange offer. The agreement featured a 26 percent haircut ${ }^{6}$ on original principal and past due and accrued interest; the issuance of a new long-term debt instrument with a 10-year maturity, a 5-year grace period, and a 6.5 percent interest rate; and a US\$40 million re-payment (comprising US\$7.5 million in cash and US\$32.5 million in short-term bonds maturing in 2021 and bearing a 6.5 percent coupon) in the period 2019-2021. In a November 23, 2019 press release, the government announced overwhelming creditor support the debt exchange, with participation well above the 75 percent threshold for the three outstanding Eurobonds (93 percent on average, and 88, 92, and 96 percent for the three instruments). Importantly, the participation rate in the Credit Suisse facility came in at 100 percent (investors in this facility had been represented in the creditor committee) - see Box 1. On December 11, 2019, the transaction closed with full creditor participation. On the same day, and in response to the completion of the debt exchange, Standard and Poor's upgraded Barbados' foreign currency sovereign credit rating from Selective Default to B-.

\section{E. Natural Disaster Clause}

Barbados is at risk of extreme weather events, as well as earthquakes, and the government of Barbados effectively used the debt restructuring to strengthen its protection against these events, in addition to existing instruments, such as its insurance under the Caribbean Catastrophe Risk Insurance Facility (CCRIF). The natural disaster clause included in most of the new debt instruments (both in the domestic and in the external debt restructuring) would allow for capitalization of interest and deferral of scheduled amortization falling due over a two-year period following the occurrence of a major natural disaster. The trigger for a natural

\footnotetext{
${ }^{5}$ Using the 12 percent discount rate that was used by the parties throughout the negotiation process to compare proposals.

${ }^{6}$ The haircut on principal and accrued interest reduces projected cashflows and therefore, for given interest rate used for discounting, their present value.
} 
disaster event for the new domestic debt is a payout above US\$5 million by the CCRIF. ${ }^{7}$ Similarly, the new external debt instruments also link the threshold for triggering the natural disaster clause to CCRIF payouts, using differentiated thresholds depending on the type of natural disaster (hurricane, flooding or earthquake). ${ }^{8}$

\section{Box 1. Credit Suisse Facility-Use of Exit Consents}

While exit consents have been a feature of bond restructurings (see Buchheit et al 2020: p. 358 ), this has been less frequently used in a sovereign loan restructuring context. Barbados made a novel use of this technique in its sovereign loan restructuring, which resulted in all of the Credit Suisse loans being exchanged for the new bonds.

The exchange offer was accompanied by a consent solicitation, which made use of the power for a majority of creditors to amend the original credit agreement in order to encourage participation in the exchange. In short, the amendments would leave potential holdouts with a less valuable instrument by stripping creditors of critical protections and enforcement powers. The structure of the original credit agreement, which included provisions allowing action by the majority given that it was to be syndicated, made this consent solicitation possible; typical bilateral loan agreements would not have the possibility of majority amendment.

The original credit agreement permitted the amendment of most provisions with a $50.01 \%$ majority of creditors. Certain provisions — such as the amount of principal—were exempted and required unanimous consent of all lenders. Under the November 5, 2019 consent solicitation, creditors simultaneously agreed to the exchange and consented to the amendment or waiver of many provisions of the credit agreement. This included removal of all affirmative and negative covenants and most events of default, which only required majority consent.

Crucially, Barbados' original submission to the jurisdiction of New York courts and waiver of sovereign immunity for any lawsuit arising out of the credit agreement was drastically narrowed to apply only to lawsuits brought by Credit Suisse as administrative agent-leaving out any actions by individual creditors. Without these two provisions, any litigation by holdout creditors would face serious obstacles when seeking to enforce any claims arising from default under the credit agreement. This approach helped secure full participation in the exchange.

\section{BARBADOS’ IMF-SUPPORTED ECONOMIC REFORM PROGRAM}

The debt restructuring was part of a comprehensive economic reform plan, aimed at restoring fiscal and debt sustainability, and supported by IMF financing. Plans for fiscal consolidation and debt restructuring were developed simultaneously, to ensure that jointly they would put

\footnotetext{
${ }^{7}$ Such a payout actually occurred right before the domestic debt restructuring exercise closed: on October 19, 2018, CCRIF made a US\$5.8 million payment to the government of Barbados following the passage of Tropical Storm Kirk, under Barbados' excess rainfall policy.

${ }^{8}$ However, for the new external debt instrument, holders of at least 50 percent of the aggregate principal amount of the bonds outstanding at the time Barbados elects to defer payments can block the activation of the clause.
} 
public debt on a clear downward trajectory and that medium-and long-term debt targets would be met. The plan sought to restore debt sustainability while at the same time maintaining broad public support for the adjustment effort, as well as financial sector stability. Program ownership (the implementation of a home-grown economic reform program, developed in close consultation with social partners) was strong from the program's inception, while careful financial sector stress tests were conducted to ensure that the domestic debt restructuring would not jeopardize financial stability.

The June 1, 2018 press release by the government of Barbados announcing the default also included a request for IMF balance of payments support. One of the new government's first actions after winning the elections of May 24, 2018 was the publication of the IMF's 2017 report on the Article IV consultation with Barbados the very next day (see IMF 2018a). Following the elections, an IMF staff team visited Barbados for an initial fact-finding visit in less than two weeks, from June 5-7, 2018. Discussions on a 4-year, 220 percent of quota (about US\$290 million) Extended Arrangement under the EFF continued during two more visits in July and in August/September, respectively. Discussions with the IMF staff on the scope and design of a program moved forward in parallel with the negotiations with creditors on the debt restructuring.

A staff-level agreement on an IMF-supported program was announced on September 7, 2018 the same day as the launch of the domestic debt exchange. This was not a coincidence: for the government's launch of its exchange offer for the stock of central government domestic debt held by private creditors consistent with program objectives was a prior action for approval by the IMF's Executive Board. The prior action was necessary as the Fund cannot lend into an unsustainable debt situation, as discussed above.

\section{A. The BERT plan}

The Barbados Economic Recovery and Transformation (BERT) plan, and the Extended Arrangement that supports it, aim to reduce the central government debt (including arrears and SOE debt guaranteed by the central government - see Table 1) from about 158 percent of GDP by the end of FY2017/2018 to 80 percent by FY2027/28 and to 60 percent by FY2033/34, ${ }^{9}$ with a combination of fiscal consolidation, debt restructuring, and measures to boost growth. Public debt declined sharply in the first year of the program, as a result of the debt restructuring, in particular the holdings of the CBB and the NIS (as discussed in greater detail below), and is projected to remain on a clear downward trajectory afterwards. In FY2019/20, both fiscal consolidation (with the government now running an overall fiscal surplus) and debt

\footnotetext{
${ }^{9}$ The debt threshold under the IMF's debt sustainability framework for emerging markets (MAC DSA) is 70 percent of GDP; however, in light of Barbados' vulnerability to natural disasters, a 60 percent of GDP debt anchor was deemed appropriate in this case, also to ensure that Barbados' debt target was aligned with that of other countries in the region, including Jamaica and the ECCU. Reaching that debt level earlier than the targeted date of 2033 would have implied either a higher primary balance path or a deeper debt restructuring (with higher financial sector losses), or a combination of the two.
} 
restructuring (in particular the 25 percent principal haircut on external debt to commercial external creditors) contributed to a decline in public debt.

\section{B. Fiscal Adjustment}

Fiscal consolidation is a cornerstone of the BERT program: in mid-2018, the new government announced its intention to raise the primary surplus to 6 percent of GDP in FY2019/20, from 31/2 percent in FY2017/18, and to maintain the primary surplus at this level for several years thereafter. Reforms of state-owned enterprises (SOEs) and Public Financial Management (PFM) reforms underpin the fiscal consolidation. To reduce

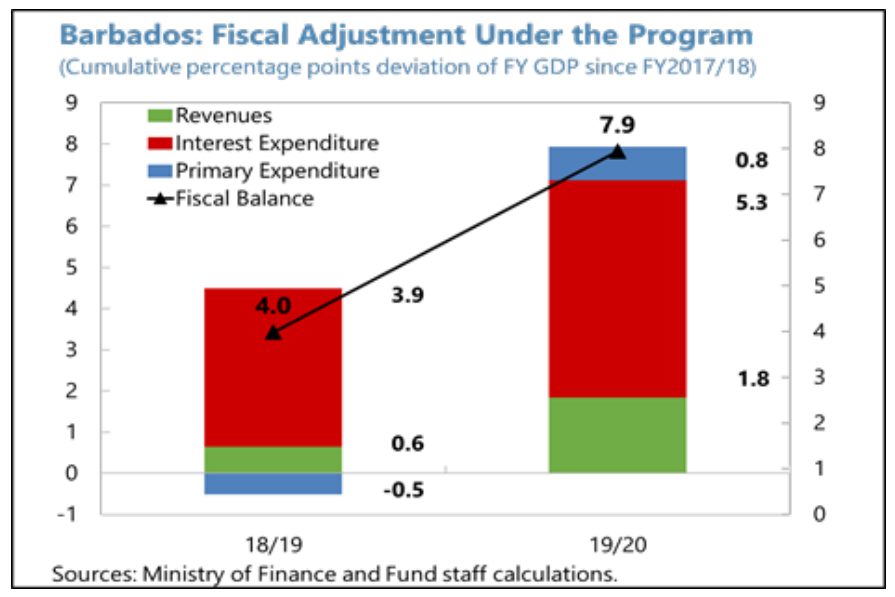
central government transfers to SOEs, the BERT plan includes measures on: (i) much stronger oversight of SOEs, supported by improved reporting; (ii) a reduction of the wage bill; (iii) revenue enhancement, starting with a review of user fees; and (iv) mergers and divestment. The adoption of a fiscal rule, planned for end-2020, will help sustain the reform effort over the medium and long term.

In June 2018, the government also took steps to improve the composition of revenue by removing a highly distortionary excise tax, the National Social Responsibility Levy (NSRL); and by introducing new taxes on tourism. By doing so, the government aimed to shift the burden of taxation from residents to non-residents - important with a view to maintaining political support for the adjustment process. Similarly, in December 2018, a corporate income tax reform aimed to shift the burden of profit taxes from resident to non-resident companies (by unifying corporate income tax rates at a level above what had been the rate for non-resident companies, but much lower than the previous rate for resident companies). This measure also aimed to ensure that Barbados was compliant with non-discrimination guidelines promoted by the OECD.

\section{Structural Reforms}

Institutional reforms to sustain prudent macroeconomic policies and avoid a repeat of the 2018 crisis are an important part of the BERT program. In addition to the fiscal rule mentioned above, public pension reform is planned for 2020, to address the rising costs of the public pension scheme in the face of an aging population. A new Central Bank law, expected to be adopted in early 2020, enhances the institutional, personal and financial autonomy of the Central Bank of Barbados, while limiting financing of the government to short term advances in normal times, with a natural disaster clause to facilitate additional financing to the central government in exceptional situations. The large monetary financing in the years leading up to 
the crisis - peaking at 8 percent of GDP in FY2016/17 - played a major role in the decline of Barbados' international reserves in the years leading up to the crisis, and jeopardized the country's exchange rate peg, with a fixed rate of two Barbados dollars to one US dollar in place since 1975 .

The BERT plan also includes structural reforms to improve Barbados' growth potential and competitiveness. The adoption of a new Town and Country Planning law in January 2019 help to streamline the process for providing construction permits. Barbados' relatively low score in the World Bank's Doing Business rankings-129 out of 190 countries in the October 2019 survey - indicates that there is ample room for further improvement in many areas, from starting a business to facilitating trading across borders, and from protecting minority shareholders to digitizing property records.

\section{BERT Monitoring Committee}

The government engaged in intensive consultations with the Social Partnership to build public support for the program. In October 2018, a BERT Monitoring Committee (BERT MC) was set up, co-chaired by the Chairman of the Private Sector Association and the General Secretary of the Barbados Workers' Union; the committee reports to the Social Partnership and the public. BERT MC started to issue quarterly press releases, with the first one issued in February 2019.

\section{RESTRUCTURING THE DEBT: OUTCOMES}

The comprehensive debt restructuring played a critical role in restoring Barbados' debt sustainability. Combined with fiscal consolidation and measures to boost growth, public debt was put on a clear downward trajectory. The maturity profile of public debt was lengthened, gross financing needs dramatically reduced, and the external debt restructuring greatly improved the external debt service profile as illustrated in the charts below. On the other side of the coin, the government's creditors incurred losses, as discussed below. 

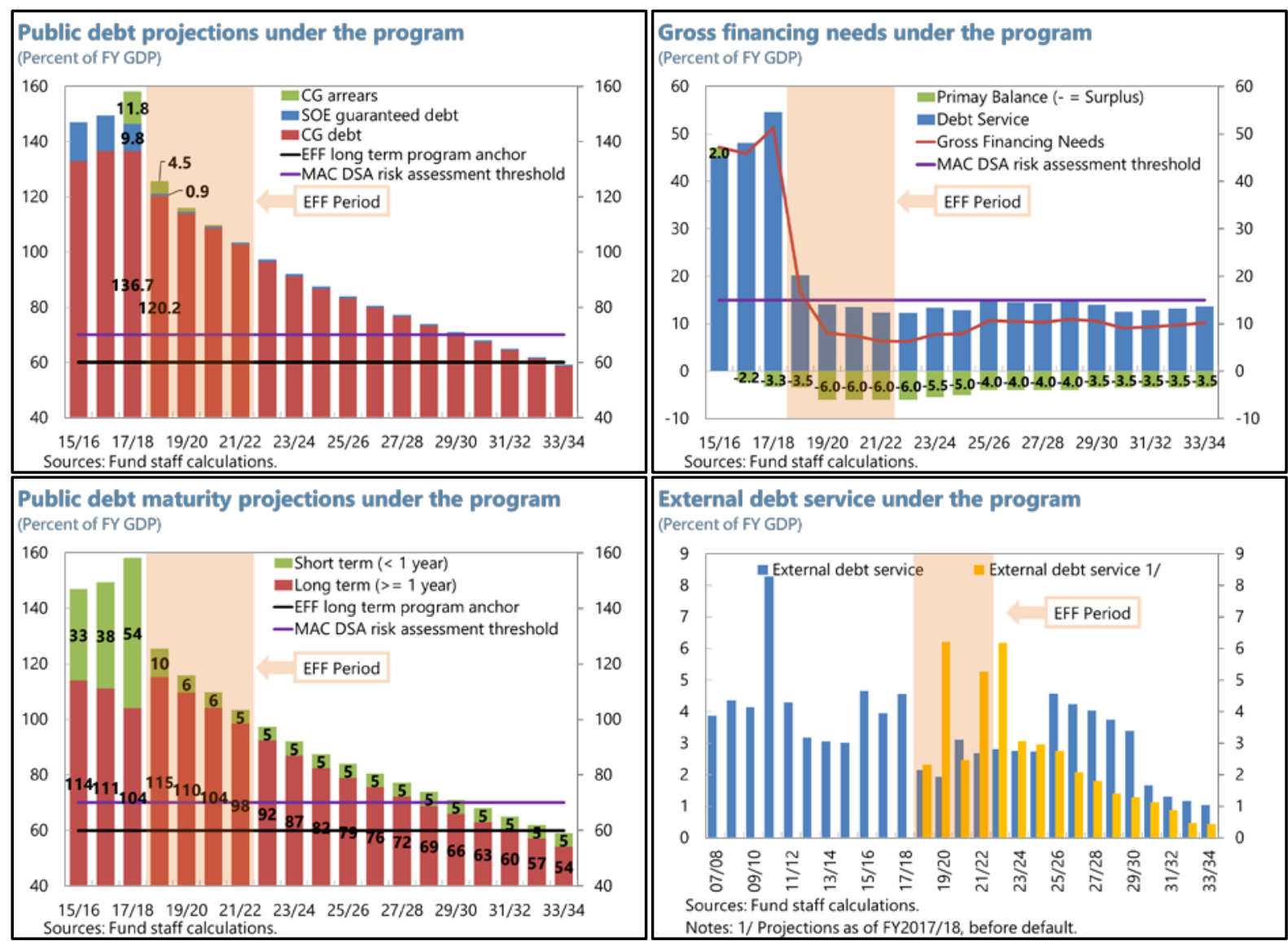

The terms of the external commercial debt restructuring announced on October 18, 2019 provided an immediate debt reduction (a face value, nominal haircut) of about 4 percent of GDP. This, together with the restructuring of the cashflows implied an NPV loss for creditors (and a gain for the government of Barbados) of about 44 percent of stock and accrued interest and penalties when measured at the discount rate of 12 percent used by the parties in the debt restructuring process. At the exit yield of 7 percent, the NPV gain for the government (and loss for creditors) would be about 30 percent.

The terms of the domestic debt restructuring proposed by the government on September 7, 2018 laid out several new debt instruments, and specified financial institutions' eligibility for these instruments. Commercial banks, life insurers, general insurers, and other financial institutions (including credit unions), were treated differently under the restructuring, while yet different modalities applied to individual debt holders, the NIS, and the CBB. ${ }^{10}$ NPV losses from the domestic debt restructuring for domestic creditors (and gains for the central government) averaged about 43 percent, with NPV losses for private creditors around 30 percent, using a discount rate of 7 percent (Table 2).

\footnotetext{
${ }^{10}$ Details of the debt restructuring can be found on http://gisbarbados.gov.bb/creditors/; the text provides a summary of the main elements of the restructuring.
} 
Table 2. Barbadlos: Aggregate NPV losses from the domestic debt restructuring

\begin{tabular}{|c|c|c|c|c|c|}
\hline Sector & $\begin{array}{l}\text { Unrestructured } \\
\text { claims at } \\
\text { nominal value } \\
\text { (B\$ million) }\end{array}$ & $\begin{array}{l}\text { Unrestructured } \\
\text { claims at PV /3 } \\
\text { (B\$ million) }\end{array}$ & $\begin{array}{c}\text { Restructured } \\
\text { claims at PV /3 } \\
\text { (B\$ million) }\end{array}$ & $\begin{array}{c}\text { Nominal to PV } \\
\text { loss } / 3 \\
\text { (Percent) }\end{array}$ & $\begin{array}{l}\text { PV to PV loss } / 3 \\
\text { (Percent) }\end{array}$ \\
\hline Public Sector & $6,265.1$ & $6,420.1$ & $2,860.1$ & -54.3 & -55.5 \\
\hline CBB 1/ & $2,640.7$ & $2,640.1$ & 642.0 & -75.7 & -75.7 \\
\hline NIS & $3,624.3$ & $3,780.0$ & $2,218.2$ & -38.8 & -41.3 \\
\hline Private Sector & $5,291.9$ & $5,443.9$ & $3,858.8$ & -27.1 & -29.1 \\
\hline Banks & $2,205.8$ & $2,223.0$ & $1,607.6$ & -27.1 & -27.7 \\
\hline Trusts & 296.8 & 303.6 & 211.4 & -28.8 & -30.4 \\
\hline Credit Unions & 130.9 & 131.2 & 91.0 & -30.5 & -30.6 \\
\hline Insurance & 523.2 & 554.5 & 391.2 & -25.2 & -29.4 \\
\hline Pension funds & 609.8 & 639.1 & 429.4 & -29.6 & -32.8 \\
\hline Other 2/ & $1,525.4$ & $1,592.4$ & $1,128.2$ & -26.0 & -29.2 \\
\hline Total Domestic Claims & $11,557.0$ & $11,864.0$ & $6,718.9$ & -41.9 & -43.4 \\
\hline
\end{tabular}

\section{A. Stress tests}

Financial sector supervisors - the CBB and the Financial Services Commission (FSC)conducted extensive stress tests over June-August 2018 to ensure that the proposed debt restructuring would not jeopardize financial stability. While the holdings of commercial banks and insurers were not subject to face-value haircuts, the NPV losses incurred by maturity extensions and interest rate reductions did lead to capital losses, under IFRS-9 applied by financial institutions and their auditors. Stress tests ensured that the proposed terms would not push financial entities below minimum capital requirements.

\section{B. Government Debt Held by Domestic Banks}

Commercial banks dominate the financial system in Barbados. On the eve of the debt restructuring (December 2017 data), banks held 53 percent of total financial sector assets. The system was highly solvent, with strong capital buffers well over prescribed levels. All five banks in Barbados are foreign owned, with three Canadian banks (Nova Scotia, RBC and CIBC First Caribbean, all three rated AAA) holding 75 percent of total bank assets, and with the two Trinidadian banks (Republic Bank Barbados and First citizens, both rated $\mathrm{BBB}+$ ) accounting for the remaining 25 percent. On average, banks had loan-to-deposits ratios of 60 
percent, and excess cash reserves of 20 percent of deposits. Banks' funding costs were and are negligible, with deposit rates close to zero (see text chart). At end-2017, the non-performing loan level for the banking system was 8 percent. Banks had large (but not uniform) exposures to the sovereign: they held about $\mathrm{B} \$ 2.2$ billion (22 percent of GDP) of claims on the government. This exposure was almost twice as much as the total capital of banks.

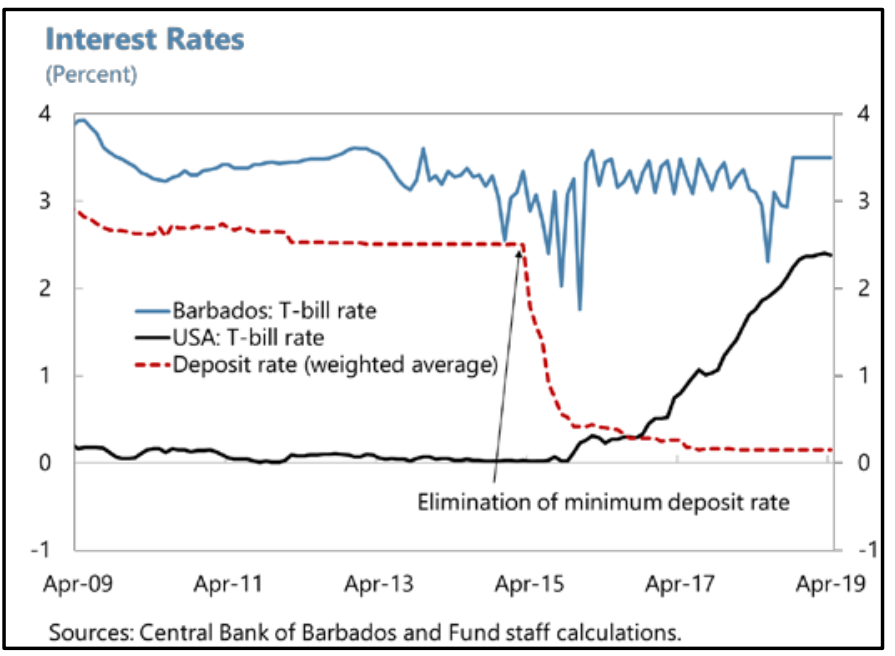

On the eve of the debt restructuring, the bulk of commercial banks' holdings of government debt was in the form of treasury bills, owing to credit risk concerns. In the years prior to June 2018, domestic banks had switched from holding government bonds to treasury bills precisely with a view to reducing credit risk (and considering that short-term debt had rarely been included in past debt restructuring operations around the world). Between FY2006/07 and FY2017/18, short term debt (mainly treasury bills) held by commercial banks increased from 6 to 18 percent of GDP.

\section{Statutory Reserve Requirements}

Part of commercial banks' accumulation of Barbados government debt had been driven by the authorities themselves: in May 2017, the CBB raised banks' statutory minimum requirement for government holdings from 10 to 15 percent of deposits, and the CBB raised this ratio again on November 1, 2017, to 18 and 20 percent with effect on December $1^{\text {st }}$ and January $1^{\text {st }}$, respectively (IMF 2018a: p. 7). This allowed the government to rely less intensively on monetary financing in FY2017/18, with CBB financing of the central government down to less than 1 percent of GDP in FY2017/18, from more than 8 percent of GDP in 2016/17. From the point of view of commercial banks, this raised a fairness issue in the debt restructuring: a part of their holdings of government debt being restructured had been acquired in compliance with government regulations, not as an independent investment decision.

The government's decision to include banks' holdings of treasury bills within the debt restructuring perimeter was prompted by both burden sharing and debt sustainability considerations. At 42 percent of GDP, short term debt was a major factor into Barbados' very high gross financing needs. In the Debt Sustainability Analysis included in the IMF's 2017 report on the Article IV consultation with Barbados (IMF 2018a), gross financing needs were flagged as a key risk to debt sustainability; these were projected to rise from about 51 percent of GDP in 2017/18 to 53 percent of GDP in 2022/23. Maturity extension of the bulk of these 
instruments was therefore important to reduce financing needs and bring them below the 15 percent of GDP threshold used to assess debt sustainability.

Commercial banks' claims were reprofiled, with no face value reductions (haircuts). Under the restructuring of treasury bills, 85 percent of the claims held by commercial banks were exchanged into 15-year bonds; this maturity extension was critical to reduce gross financing needs and thereby restore debt sustainability. The interest rate on the new instrument is 1 percent for the first three years, 2.5 percent for year 4 , and 3.75 percent for the

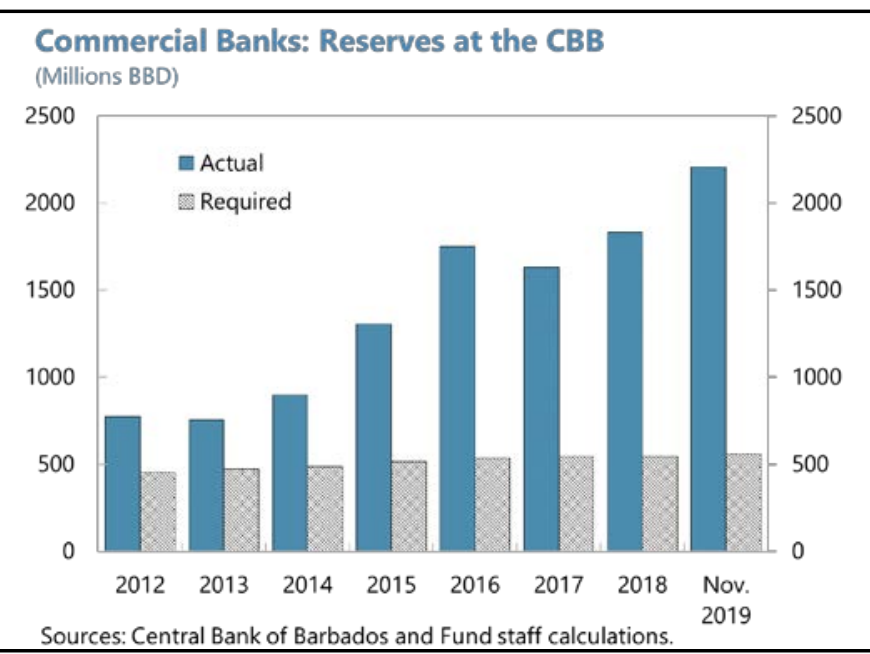
remaining years up to maturity. For the first three years, this entails a significant reduction in interest rates from what prevailed prior to the debt restructuring (about 3 percent). The remaining 15 percent of commercial banks' holdings of treasury bills was converted into new 90-day treasury bills, to be rolled over for 10 years (to meet CBB reserve requirements), with an interest rate of 0.5 percent. This 15 percent carve-out aims to provide banks with a shortterm instrument for liquidity management purposes. In addition, banks have excess liquidity parked in the form of excess reserves at the central bank (see text chart) amounting to about $\mathrm{BRB} \$ 16 \frac{1}{2}$ million (or 16 percent of GDP) as a consequence of the liquidity overhang stemming from several years of rapid money supply expansion and continued credit demand constraints resulting in a very low loan to deposit ratio of about 60 percent. Commercial banks' loss on its holdings of government debt amounted to 27 percent in NPV terms (see Table 2)ensuring an important contribution to public debt sustainability, while at the same time maintaining adequate capitalization of the banking sector.

\section{Government Debt Held by Insurers}

On the eve of the restructuring, insurance companies held about 7 percent of GDP in government debt (see Table 1), and the sector had large solvency buffers. Government debt held by general insurers was treated differently from that held by life insurers: a part of general insurers' debt holdings were exchanged for debt without a natural disaster clause, as general insurers argued that they would need liquidity in case of a natural disaster, as much as the government would. Conversely, for life insurers, all newly issued instruments contained a natural disaster clause. For both general insurers and life insurers, the maturity of the newly issued debt was in part 15 years, and in part 35 years. A specific agreement was reached with Sagicor, the largest insurer. All of its holdings of government debt were converted into a 50- 
year amortizing bond, including a 15-year grace period, with an interest rate of 4 percent during the first 15 years, stepping up to 8 percent over years 25-50 (see Barbados 2018b). ${ }^{11}$

\section{E. Government Debt Held by the Central Bank of Barbados}

Owing to significant monetary financing, the Central Bank of Barbados (CBB) acquired a large stock of government debt over the last decade, held mainly in the form of treasury bills, at around 15 percent of GDP on the eve of the debt restructuring. The CBB claims on the central government were restructured in a separate operation, on terms different from those that applied to commercial banks. A nominal haircut (face value reduction) of about 16 percent of GDP was applied to the CBB's claims on

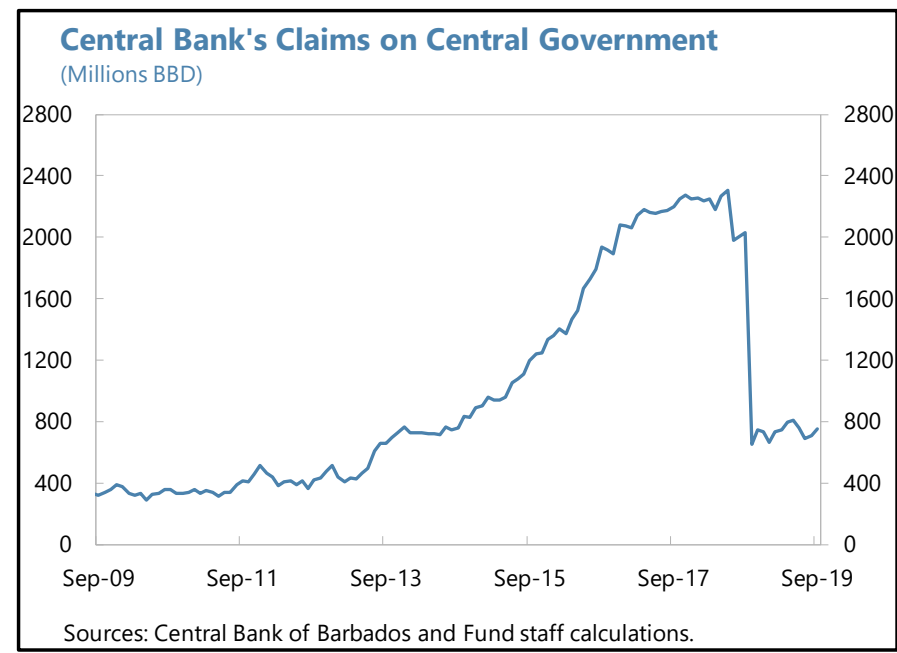

Sources: Central Bank of Barbados and Fund staff calculations. the government. The remaining claims were replaced by a portfolio of equally-weighted tradable benchmark treasury notes and debentures with maturities ranging from 5-25 years and a portfolio of 6-month T-bills, priced from the CBB's June 1, 2018 yield curve. This new portfolio contributes sufficiently to the income the $\mathrm{CBB}$ requires to meet its expenses. At the same time, the securities provide the $\mathrm{CBB}$ with the instruments it requires to implement its monetary policy. The benchmark treasury notes and debentures also help to preserve a domestic government yield curve and facilitate pricing of corporate securities and the return to normal functioning of domestic capital market post-restructuring. The implied NPV loss for the CBB on its holding of government debt was 76 percent (using a discount rate of 7 percent)see Table 2. After the restructuring, the CBB's capital now stands at minus B $\$ 1.6$ billion, or a negative 16 percent of GDP. In 2020, a plan to gradually recapitalize the CBB will be developed.

\section{F. Government Debt Held by the National Insurance Scheme}

On the eve of the restructuring, the NIS had about B $\$ 5$ billion (50 percent of GDP) in reserves. Of these, central government securities accounted for B $\$ 3.6$ billion (36 percent of GDP), almost exclusively in long term securities. The rate of return on both its government and noncentral government assets averaged about 7 percent, respectively, before the restructuring.

In the debt restructuring, short-term and long-term claims on government were treated differently. The NIS' (small) holdings of treasury bills were converted into the same 15-year

\footnotetext{
${ }^{11}$ Life companies had an asset-liability structure that favored this type of debt reprofiling. Life companies had excess assets over liabilities for maturity buckets of up to about 5 years while they had excess liabilities at longer maturities. Hence, a lengthening of the maturity structure of their claims, while producing an NPV loss, would also improve asset liability matching. This in turn would free capital and reserves set aside for the mismatch.
} 
instrument that was used to extend the maturity of commercial banks' holdings of treasury bills, paying 1 percent interest for the first 3 years. Holdings of longer-term government debt were converted into a 25 -year bond with a 37.5 percent nominal haircut (about $\mathrm{B} \$ 1.3$ billion), paying 4 percent for the first 3 years, and 8 percent thereafter. This implied an NPV loss for the NIS of 39 percent, using a discount rate of 7 percent (table 2).

As a result of the debt restructuring, NIS liquidity decreased, and its reserves are expected to be depleted 10 years earlier than before the restructuring (see text chart). Before the restructuring, asset cashflows were projected to exceed liability cashflows until 2031-32. At this point, the NIS would have sold reserves to pay for current expenditures and reserves were projected to exhaust in 2052-53. After the debt restructuring, asset cash flows are reduced between 2019-22. The operating balance is expected to become negative around 2027-28, or about 5 years earlier than had been projected prior to the debt restructuring. Lower investment income and the BRB $\$ 1.3$ billion upfront haircut (13 percent of GDP, or 26 percent of the NIS' reserves) result in reserves being expected to be exhausted around 2040-41, 10 years earlier than expected prior to the debt restructuring. Systemic or parametric pension reform is envisaged in the medium term to strengthen the financial position of the NIS.
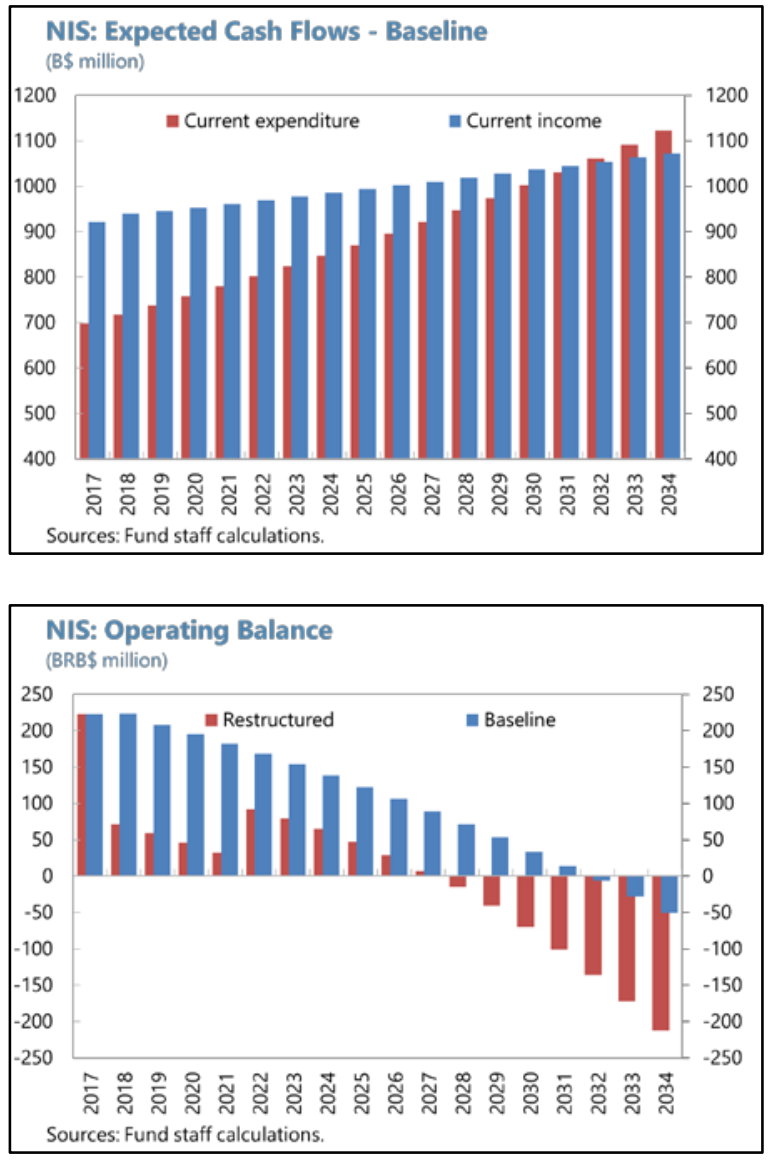
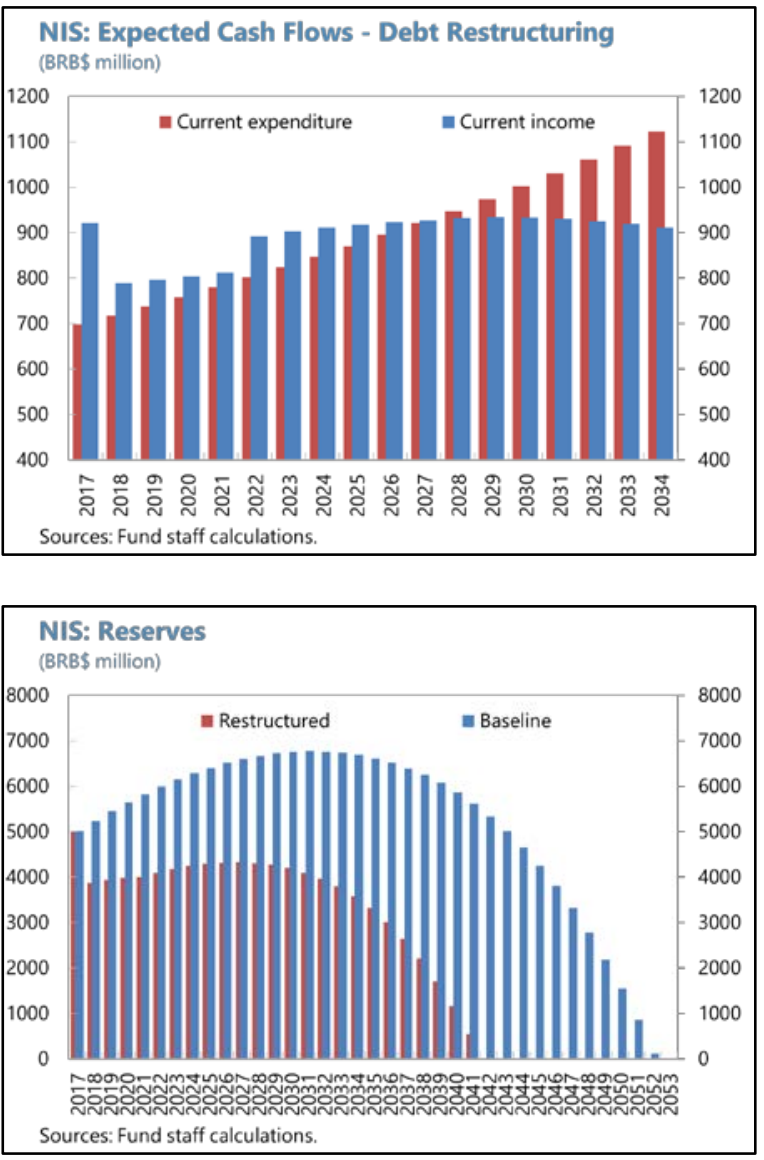


\section{Barbados’ Debt Restructuring in a Regional and Global Perspective}

Barbados' debt restructuring did not entail major innovations, but it did feature several elements that are infrequently encountered in sovereign debt restructurings, in particular (i) the inclusion of treasury bills, (ii) the retrofitted collective action mechanism into domestic debt, and (iii) the inclusion of a state-contingent element in the restructured domestic and external debt - the natural disaster clause. This section puts Barbados' debt restructuring in a regional and global perspective, highlighting selected key characteristics.

\section{A. Perimeter: Including Treasury Bills}

Treasury bills are rarely included in debt restructuring operations, with a view to keeping a critical source of short-term credit for the government open, and also to avoid impacting financial markets that may use short-term government paper as collateral, for example the interbank market. Moreover, the stock of government debt held in the form of treasury bills is typically not very large, implying that treasury bills do not need to be restructured for the government to secure significant debt relief (in NPV terms) in its debt restructuring. However, in the case of Barbados, the stock of treasury bills had ballooned to 39 percent of GDP, with commercial banks having converted the bulk of their holdings of government debt into this instrument in the years leading up to the debt restructuring. The government therefore decided that treasury bills had to be included in the restructuring, both to ensure adequate burden sharing in the economic adjustment process, and to reduce gross financing needs.

Barbados experienced no major losses or downsides from the inclusion of treasury bills in the operation. With financial markets relatively underdeveloped, and no meaningful interbank market to start with, not being able to use treasury bills as collateral was not a significant cost in the case of Barbados. Following the debt restructuring, the government of Barbados started running an overall fiscal surplus, and after IMF Executive Board approval of the Extended Arrangement, multilateral banks (the Inter-American Development Bank and the Caribbean Development Bank) swiftly approved policy loans for Barbados; as a result, there was no remaining need for domestic financing following the debt restructuring. With careful stress testing conducted by financial sector supervisors (CBB and FSC), and in the absence of nominal haircuts in the domestic debt restructuring, no financial entity experienced major liquidity or solvency issues on account of the debt restructuring. This in contrast to other cases where treasury bills were included in the restructuring: for example, when Russia restructured its short-term government debt (GKOs) in 1998, this contributed to a severe banking crisis, with a bank run and widespread bank insolvencies (see Das et al. 2012: p. 64).

\section{B. Post-Default vs Pre-Default}

Barbados' debt restructuring was post-default - a choice that may have been determined by a very tight timeline, with a new government taking office just a few weeks ahead of large external debt payments falling due; if the government had decided to make these payments, reserves would have fallen to dangerously low levels, covering less than a month of imports. 
This sets the Barbados case apart from most of the recent cases in the region, with both Jamaica and Belize repeatedly opting for a pre-default (or preemptive) approach. In their extensive survey over sovereign debt restructuring globally over six decades, Das et al. (2012) count 109 post-default cases, while 77 were preemptive; i.e., globally post-default is slightly more common.

\section{Duration of the Debt Restructuring Operation}

The operation was announced on June 1, 2018 and wrapped up on December 11, 2019, hence it took 18 months. This was faster than Grenada's 2013-15 operation (which took 2 $\frac{1}{2}$ years), but slower than Jamaica 2010 or 2013 (in both cases a few months). The average debt restructuring in the Caribbean over the last decade, and not including Barbados' debt restructuring, took 131/2 months (see Asonuma et al. 2018, p. 16). Factors that contributed to the duration of the operation include:

(i) the complexity of the operation: Barbados undertook a comprehensive debt restructuring, as in the case of Grenada 2013-15, but unlike the two Jamaica operations, which covered domestic debt only; external debt restructuring typically involves a diverse set of creditors, spread geographically, which can make the operation more complicated.

(ii) relatively quick agreement on an IMF supported program, and subsequent strong performance under the program, with the timely conclusion of the first and the second EFF review, helped to move the debt restructuring process forward, as this provided assurances to creditors that the government was serious about adhering to its side of the bargain —increasing the primary surplus to 6 percent of GDP, and maintaining this stance for several years thereafter, with both an international (IMF) and a domestic monitoring process in place.

(iii) domestic administrative capacity in Barbados may be higher than in the case of Grenada, where it contributed to the long duration of the operation (Okwuokei and van Selm 2017: p. 163).

Duration matters: it is important to keep the process as short as possible, to avoid a negative impact on economic activity. Especially in cases where domestic debt restructuring is an important part of the operation, financial institutions may be hesitant to engage in new investments until it is clear what the impact of an announced debt restructuring operations will be on their balance sheets. Barbados' debt restructuring was successful in keeping the duration of the operation limited, especially the domestic debt restructuring, which was wrapped up in 5 months.

\section{NPV Gains}

A central objective of any public debt restructuring operation is to help public finances regain a sustainable footing; the NPV gain of the operation is a key indicator. In the Caribbean, in debt restructurings over the last decade, post-default debt restructurings have generally been able to 
secure higher NPV gains for the government, in the range of 50-100 percent (Asonuma et al. 2018b: p. 21). In cases where a restructuring of domestic debt takes center stage, NPV gains are typically lower, as meaningful debt relief for the government needs to be weighed against the importance of maintaining financial stability.

The NPV gains realized in Barbados' debt restructuring operation fit into this pattern. The NPV gain on government domestic debt to private creditors was around 30 percent (see Table 2) - a somewhat higher gain for the government than in the 2010 and 2013 domestic debt restructuring operations in Jamaica, which featured NPV gains of around 15-25 percent but lower than the domestic NPV gain in the 2013-15 Grenada operation, at 54 percent (see Asonuma et al. 2018a: p. 83).

Barbados' NPV gain in its external debt restructuring operation is estimated at 44 percent (using the 12 percent discount used by the parties during the debt negotiation process), or 30 percent using the exit yield of 7 percent. This compares favorably to the NPV gains realized in Belize's three pre-default external debt restructurings over the last decade, which each netted NPV gains in the range of 20-30 percent; but it was a bit lower than the gain realized by Grenada in its post-default 2013-15 operation (at 49 percent — see Asonuma et al. (2018b, p. 20)).

\section{E. Natural Disaster Clause}

A natural disaster clause was included in the bulk of the new domestic instruments and also in the new external debt instrument, following an approach taken in Grenada's 2013-15 debt restructuring. The trigger used in the two cases are similar, in both cases linked to payouts under the Caribbean Catastrophe Risk Insurance Facility, or CCRIF. A difference is that in Grenada's restructuring, debt payments would be deferred for up to one year after a qualifying event, whereas in the case of Barbados, the clauses allows for the capitalization of interest and the deferral of scheduled amortization falling due over a two-year period. State-contingent instruments have been a component of several sovereign debt restructurings, following the Brady deals from 1989-97 (IMF 2017: p. 20). ${ }^{12}$

\section{F. The Retrofitted Collective Action Mechanism}

In Barbados' debt restructuring, the bulk of the instruments to be restructured were issued under domestic law, and these did not contain collective action clauses. Holdout creditors were seen as a risk. To address this, parliament passed a law to retrofit a collective action mechanism into domestic debt. A similar approach was used also in Greece's 2012 debt restructuring (see Zettelmeyer et al. 2012: p. 11): in February 2012, Greek parliament adopted a law that allowed for the restructuring of Greek-law bonds with the consent of a qualified

\footnotetext{
${ }^{12}$ In 'normal', non-crisis times, use of state-contingent elements in government debt has been limited. In the Caribbean region, an important exception is the state-contingent debt issued under the PetroCaribe arrangement with Venezuela, but Barbados did not participate in this scheme. See IMF (2017: p. 17).
} 
majority. This approach had been suggested in a paper by Gulati and Buchheit (2010), who labeled it a 'Mopping-Up Law' as it aims to deal with hold-out creditors. This approach has some risks, as it could be subject to a legal challenge (Gulati and Buchheit 2010: p. 12) — but with Barbados' 2018 debt restructuring, there are now two recent examples of successful application. As long as such legislative changes pass muster under the country's constitutionincluding constitutional protections for property rights - they should be valid for debt instruments like those in Barbados; a change in local law is a risk that investors take when buying local-law governed debt instruments (see Buchheit et al. 2020: p. 356).

\section{G. The Role of the IMF}

As mentioned above, the newly elected government requested IMF balance of payments support within a week of assuming office, with a call to IMF Managing Director Lagarde on the evening before the public announcement of the debt restructuring (Barbados 2018a: p. 2).

Most, but not all, recent debt restructuring operations in the Caribbean have been conducted in the context of IMF financial engagement, with Belize's three restructurings of its external debt over the last decade as the main exception. Embedding the debt restructuring in a broader economic reform program, supported by the IMF, ensures that the focus of the debt restructuring is on medium and long-term debt sustainability, not just on short-term liquidity gains (Okwuokei and van Selm 2017: p. 158). This may help to reduce the risk of repeated debt restructurings.

Whether or not an IMF member's debt should be restructured is a decision of the member. However, where the Fund has determined that the member's debt is unsustainable, it is precluded from providing further financing unless measures are taken to restructure the debt in a manner that provides for medium-term debt sustainability.

\section{IMF conditionality on the debt restructuring operation}

These underlying IMF-supported programs typically entail a form of conditionality related to the debt restructuring, as it is a critical part of a package of measures needed to regain fiscal and debt sustainability, and macroeconomic stability. In some cases, finalization of the debt restructuring is required prior to IMF Executive Board approval of the program (as in Jamaica's 2010 and 2013 debt restructurings, and also Uruguay 2003) while in other cases, conditionality relates to a step towards restructuring (for example Grenada 2014, St Kitts and Nevis 2012, and also the Dominican Republic in 2005). Different approaches have been considered appropriate in different cases (see IMF 2015: p. 56). In post-default cases, such as Barbados 2018, program conditionality has typically focused on intermediate steps towards debt restructuring, as opposed to the finalization of the debt restructuring (IMF 2015: p. 57). A key consideration is to find a balance between making sure that program financing assurances are in place and the debt restructuring delivers the required debt relief, while avoiding providing creditors with undue leverage. 


\section{Lending into arrears}

From June 1, 2018 onwards, Barbados started to accumulate arrears on its debt to external commercial creditors; IMF lending in October 2018 (approval of the Extended Arrangement), June 2019 (first EFF review) and December 2019 (second EFF review) took place on the basis of the IMF's Lending into Arrears (LIA) Policy, as the authorities' discussions with external creditors had not been completed at that point. Under this Policy, the Fund can provide financing to a member with sovereign arrears to external private creditors if prompt Fund support is considered essential for the successful implementation of a member's adjustment program, and the member is making good faith efforts to reach a collaborative agreement with creditors (see IMF 2015: p. 51). The LIA Policy is used in post-default debt restructuring cases, where arrears have already arisen (e.g., in Grenada in 2014, at the time of the Extended Credit Facility approval), St. Kitts and Nevis in 2011 (approval of the Stand-By Arrangement, or SBA), and the Seychelles in 2008 (also an SBA). In the case of Barbados, the LIA Policy allowed the Fund to provide vital balance of payments support at a time when reserves where very low, at just 5-6 weeks of reserve coverage, thereby helping to restore confidence in the country's macroeconomic framework.

\section{LESSONS LEARNED AND CONCLUSION}

Barbados' 2018-19 debt restructuring has made an important contribution to restore debt sustainability. It has reduced public debt and put it on a clear downward trajectory. To ensure that it stays on that path, sustained prudent fiscal policy will be required. Debt restructuring can work as a policy response to an exceptional situation - while repeatedly restructuring the same debt is detrimental to market development and access, and to government credibility (see Okwuokei and van Selm 2017: p. 168).

Barbados' debt restructuring also provides important evidence that rarely used approaches, such as the inclusion of treasury bills and a retrofitted collective action mechanism, can make an important contribution depending on country specifics, and with the support of strong financial and legal advice. The collective action clauses included in Barbados' Eurobonds were similarly important to avoid holdout creditors.

In an age of climate change, the inclusion of natural disaster clause in the bulk of Barbados' new public debt instruments is a critical element of the country's financial resilience. While Barbados appears less vulnerable to natural disasters than other Caribbean states (see IMF $2019 b$ ), climate change is likely to increase its vulnerability, and a weather-related event could have a major impact on its economy.

The success of Barbados' underlying economic reform program BERT also contains important pointers for a successful adjustment effort, including strong ownership and the establishment of a domestic monitoring team with broad participation. Other successful reform efforts in the region, including Jamaica from 2013-2019 and Grenada's 2014-17 IMF-supported program, also used this approach. 
Finally, successful debt restructuring is a balancing act. The right balance between fiscal adjustment and debt restructuring, and between improving public finances while maintaining financial sector stability, needs to be found. Early results from Barbados' adjustment program are encouraging and indicate that it has been able to find the right balance. However, reducing public debt to prudent levels - the targeted 80 percent of GDP by FY2027/78 and 60 percent by FY2033/34 — will require sustained efforts, not only by maintaining a cautious fiscal policy, but also by aggressively exploiting opportunities to increase growth.

\section{REFERENCES}

Asonuma, M.X. Li, M.G. Papaioannou, S. Thomas, and E. Togo, 2018a, "Sovereign Debt Restructurings in Grenada: Causes, Processes, Outcomes, and Lessons Learned," Journal of Banking and Financial Economics, Vol2(10), pp.67-105.

Asonuma, T., Michael G. Papaioannou, E. Togo, and B. van Selm, 2018b, "Belize's 2016-17 Sovereign Debt Restructuring—Third Time Lucky?” IMF Working Paper No. 18/121. Washington: International Monetary Fund.

Asonuma, T., and C. Trebesch, 2016, "Sovereign Debt Restructurings: Preemptive or Postdefault," Journal of the European Economic Association, Vol.14(1), pp. 175-214.

Barbados (2018a), Ministry of Finance and Economic Affairs, Press Release, June 1, 2018. Barbados (2018b), Ministry of Finance and Economic Affairs, Press Release, September 7, 2018.

Barbados (2018c), Ministry of Finance and Economic Affairs, Press Release, October 15, 2018.

Barbados (2019a), Ministry of Finance and Economic Affairs, Press Release, May 21, 2019.

Barbados (2019b), Creditor Update, June 11, 2019.

Barbados (2019c), Ministry of Finance and Economic Affairs, Press Release, October 18, 2019.

Barbados (2019d), Ministry of Finance and Economic Affairs, Press Release, November 5, 2019.

Barbados (2019e), Ministry of Finance and Economic Affairs, Press Release, November 26, 2019.

Barbados External Creditor Committee (2018a), "Notes IMF Agreement, Expresses Disappointment with Process", Boston and New York, September 11, 2018.

Barbados External Creditor Committee (2019a), "Ready to Continue Discussions with Barbados to Resolve the External Commercial Debt Default", Boston and New York, May 29, 2019. 
Barbados External Creditor Committee (2019b), "Negotiations to Reach Consensual Resolution is the Best Path to Resolve the External Commercial Default", Boston and New York, June 14, 2019.

Barbados External Creditor Committee (2019c), Government of Barbados Launches Exchange Offer to Resolve the External Commercial Default, Boston and New York, November 6, 2019.

Buchheit, L., G, Chabert, C. DeLong, and J. Zettelmeyer (2020), “The Restructuring Process", in S. Ali Abbas, A. Pienkowski, and K. Rogoff eds, Sovereign Debt: A Guide for Economists and Practitioners, Oxford, pp. 328-364.

Das, U., M. Papaioannou, and C. Trebesch, 2012, "Sovereign Debt Restructurings 1950-2010: Literature Survey, Data, and Stylized Facts", IMF Working Paper No. 12/203. Washington: International Monetary Fund.

Gulati, M, and L.C. Buchheit (2010), "How to Restructure Greek Debt", Duke Law Working Paper 47.

IMF (2015), “The Fund's Lending Framework and Sovereign Debt—Further ConsiderationsAnnexes", IMF Policy Paper April 2015.

IMF (2017), "State Contingent Debt Instruments for Sovereigns”, IMF Policy Paper May 2017.

IMF (2018a), "Barbados: Staff Report for the 2017 Article IV Consultation”, IMF Country Report 18/133, Washington, D.C.

IMF (2018b), "Barbados: Request for an Extended Arrangement under the Extended Fund Facility", IMF Country Report 18/290, Washington, D.C.

IMF (2019a), "Barbados: First Review Under the Extended Arrangement and Request for the Completion of the Financing Assurances Review and Modification of Performance Criteria", IMF Country Report 19/182, Washington, D.C.

IMF (2019b), "Barbados: Second Review Under the Extended Arrangement and Request for the Completion of the Financing Assurances Review and Modification of Performance Criteria”, IMF Country Report 19/XXX, Washington, D.C.

Jahan, S. 2013. "Experiences with Sovereign Debt Restructuring: Case Studies from the OECS/ECCU and Beyond," in Schipke, A., A. Cebotari, and N. Thacker, eds. The Eastern Caribbean Economic and Currency Union: Macroeconomic and Financial System. Washington: International Monetary Fund.

Okwuokei, J., and B. van Selm, 2017, "Debt Restructuring in the Caribbean-the Recent Experience," in Unleashing Growth and Resilience in the Caribbean, edited by T. Alleyne, I. Otker, U. Ramakrishnan and K. Srinivasan. Washington, DC: International Monetary Fund.

Robinson, M., 2015, “Assessment of Debt Restructuring Operations in Commonwealth Small States", The Commonwealth Economic Paper 94. 
Zettelmeyer, J., C. Trebesch, and M. Gulati, 2013, "The Greek Debt Restructuring: An Autopsy”, Peterson Institute for International Economics Working Paper 2013-8. 